\title{
Medium, Small and medium Enterprises and Digital Platforms
}

A new business platform is a must for companies that disrupt new technology, especially in the era of the Covid 19 pandemic. However, many incumbent companies are less able to keep up with changing business trends. To anticipate all changes in the competitive climate in the digital era in carrying out corporate transformation programs in line with the implementation of good corporate governance values to avoid verbal dangers and a greater risk of failure.

The results of a survey conducted by the Central Statistics Agency of the Republic of Indonesia (September 2020) explained that there was a decline in the income of micro and small businesses by $84 \%$ and medium and large businesses by $82 \%$. The sharpest declines occurred in accommodation, food and beverage, other services, transportation and warehousing, the service sector, construction, manufacturing and trade. Furthermore, the results of a survey conducted by the Asia Development Bank (April-May 2020) in 4 countries such as Indonesia, the Philippines, Thailand and Laos involving 3,831 MSME respondents explained that the contribution of MSMEs to Gross Domestic Product in these 4 countries was more than 50\%. . The implementation of regional restrictions has a negative impact on MSMEs, but some MSMEs continue to operate despite experiencing a decline in income of more than $40 \%$. Based on the results of the ADB survey, it is known that $61.1 \%$ of MSMEs in Indonesia reduced the number of workers in March 2020, 59.8\% of MSMEs reduced workers in April 2020. The Covid-19 outbreak had a negative impact on $84.7 \%$ of MSMEs, the average income fell significantly by $53 \%$ and around $72 \%$ of MSMEs experienced a decrease in income of more than $40 \%$. Facts show that 62.4 million MSMEs in Indonesia are able to absorb 97\% of the workforce, contribute to Gross Domestic Product around 61\% and contribute to exports 14\%. (BPS, 2020).

Based on current conditions, the government must focus more on controlling the Covid-19 pandemic so that confirmed cases can be reduced and give confidence to the public, especially the middle and upper classes, to return to shopping and restore consumption, given Indonesia's growing economic condition. This growth is still supported by household consumption expenditure. Increased consumption and people's purchasing power will prevent Indonesia from an economic recession, considering that economic recovery under the scenario of graph $\mathrm{V}$ is still possible, especially since the budget provided by the government is quite large in 2020 or Rp. 203.9 trillion for social protection during the handling of Covid-19, but the economic recovery will not be evenly distributed in all sectors. The government has prepared various scenarios to save small and ultra-micro businesses affected by Covid-19, namely the protection and rescue of MSMEs, ranging from social assistance, tax incentives, relaxation and credit restructuring, to expansion of financing. The economic recovery program is aimed more at MSMEs, which contribute $99 \%$ to the national economy. Various economic recovery programs have been designed by the government, such as the distribution of Presidential Assistance for microenterprises, distribution of salary subsidies for formal workers through the Employment Social Security Administration (BPJS Ketenagakerjaan), launching the MSME website, and launching the MSME Digital Market for the purchase of domestic MSME products. 
According to the Ministry of Cooperatives and MSMEs, the number of MSMEs that utilize digital technology is only 8 million or about $13 \%$ of the total MSMEs. The low number of MSMEs using digital technology is due to constraints in mastering digital technology due to constraints in mastering online payment technology. Thus, integrating MSMEs in digital technology requires well-planned strategies and policies across institutions and sectors. Likewise, social engineering needs to be planned to change the pattern of work behavior of MSMEs towards working online, starting from the supply chain system, production, promotion and marketing, to payments, especially in order to compete with MSMEs from other countries.

Various strategies have been carried out by players to excite small shops and small businesses, ranging from being a channel, online bank payment points for various digital transactions by smart agents, online to offline businesses, to providing education to shop owners or small businesses to they manage the business well, efficiently and effectively. So far, the number of business actors who have entered the digital ecosystem is still relatively small, meaning that solutions and innovations are urgently needed for the digitization of MSMEs. However, the process of digitizing MSMEs cannot happen immediately and it is best to join an electronic commerce provider such as: Shopee, Tokopedia and Bukalapak.

Digitalization has proven to be able to open up inclusiveness and electronification in Indonesia. The digitization and electronification of these services can actually support economic recovery programs, such as the distribution of social assistance and financing for MSMEs. Electronification makes the distribution of social assistance more targeted and timely, which in turn will have an impact on increasing domestic consumption as the main support for national economic growth. Digitalization of payment and financing systems has the potential to open financial access for 62.9 million MSMEs and $51 \%$ of the population (91.3 million people) who have not yet reached banking access.

MSMEs must be able to work on local advantages to produce special products so that they can be more competitive in both the domestic and international markets. Therefore, MSMEs need to develop these unprocessed products into special products to fill the global market. The special product market is a form of market that must be worked on by MSMEs, considering the uniqueness or locality of MSME products in the creative field has its own selling value compared to products that are mass produced. 


\section{Reference}

Tayibnapis, A. Z., Wuryaningsih, L. E., \& Gora, R. (2021). Medium, Small and Medium Enterprises and Digital Platforms. South Asian Journal Of Social Studies and Economics. 